\title{
Customer Service Factors Influencing Internet Shopping in New Zealand
}

\author{
Zhuojun Zhao and Jairo A. Gutiérrez \\ University of Auckland, Auckland, New Zealand
}

zhao zhuojun@yahoo.com, j.gutierrez@auckland.ac.nz

\begin{abstract}
Recent e-commerce failures caused by poor e-customer service have motivated many researchers to explore the factors that influence e-customer service quality, which leads to business-toconsumer (B2C) e-commerce success. The research reported in this paper explored the perceptions of a group of New Zealand e-customers and e-users about e-customer service and the influence of their perceptions on their attitudes towards Internet shopping. The study findings strongly indicate e-customers are only moderately satisfied with current e-customer service. Conversely, New Zealand e-users (i.e.: not yet "customers") are discouraged from using the Internet for shopping due to issues such as credit card security, resistance to change, lack of physicality, hard-totrust online vendors, and the perceived insecurity of payment systems. The study found that the motivators to Internet shopping are: goods returns and refunds policy, privacy protection, timely online service, ease of use, help and support facilities. Based on these findings, some recommendations on e-customer service for Internet shopping are presented.
\end{abstract}

Keywords: e-customer service quality, Internet shopping, B2C, online vendors

\section{Introduction}

Recent reports show that more than half of New Zealand Internet users have not shopped on the Internet and many companies are only slowly implementing e-commerce capabilities ("New Zealand Firms," 2002; "Retailing," 2000). It is becoming apparent that in order to encourage more consumers to be involved in the e-shopping world, e-tailers need to provide a good shopping experience on their sites, in special quality e-customer service. Today, customers have more choices, and can quickly and easily switch to a competitor on the Internet. Serving customers on the Internet is much harder. After all, 'the competition is just a click away' (Zemke \& Connellan, 2001). Many recent e-commerce failure stories are due to poor e-customer service (e.g. Hendrickson \& Gianforte, 1999; Sukpanich \& Chen, 2000; Tehrani, 2000). These facts have motivated a number of researchers to explore the critical factors that influence e-customer service (e.g. Muthitacharoen, 2000; Rose, Straub, \& Lees, 2000; Sukpanich \& Chen, 2000; Webb, 2000 among others). The purpose of this paper is to present the results of research that evaluated current ecustomer service experiences for a group of New Zealand shoppers, discovered the key motivators and barriers to Internet shopping, and determined what the important Internet shopping features are from their perspective. The paper provides a comprehensive survey of critical success factors for online customer service and highlights the importance of building online communities.

\section{Online Customer Service}

Poor customer service will discourage customers from doing Internet shopping even faster than in a traditional shopping environment. Nowadays, people have many choices and expect high quality service. E-business success or failure is greatly determined by whether customers are satisfied 
or not (Pastore, 2000). If customers are satisfied, they will buy more, and more importantly, they may become active referral sources via various fast communication channels (Wesler, 2001). On the contrary, dissatisfied customers will tell other people about their bad experience quickly through the Internet, and can, with only one click, quickly and easily switch to competitors' sites (Abrams, 2000; Ferrara, 2000). As e-commerce keeps growing, online customer service quality may become a dominant factor of attracting a consumer to shop on a site (Jovin \& Lach, 1999).

\section{Online Customer Relationship}

Customer relationships have become an important aspect of e-commerce success as it is harder to build trust and customer loyalty in an intangible and uncertain business environment.

\section{Online Customer Relationship and Customer Loyalty}

Seybold (1998) suggests that to successfully build online relationships with customers, e-tailers should keep their customers in mind, do not waste their customers time, make online purchase easy for customers, and provide their customers with customized products and services. Since acquiring new customers is more expensive than managing existing customers (McCall, 2000), Customer Loyalty, measured in repeat purchases and referrals, has become the main source of ebusiness profit (Brodsky, 1997). Additionally, how much a customer can purchase on a website is greatly determined by his or her online shopping experience. Just one bad experience may cause them never to go back to this site (Hanover, 1998).

\section{Interactive Communications}

In order to reduce customer perceptions of uncertainty and risks, and build trust on the Web, efirms need to interactively communicate with their customers (Zhao \& Gutiérrez, 2001). Sukpanich and Chen (2000) argue that higher interactivity leads to a higher level of trust and higher levels of trust brings about a positive effect on customers intention to purchase. They consider interactivity as a 'driving force' behind e-commerce and an important role in consumer purchasing decisions. Wesler (2001) points out that frequently communicating with clients could earn customer satisfaction. Customer expectations are surpassed because they are contacted before they get tired of waiting. Ferrara (2000) says that providing answers to frequently asked questions (FAQs) and search capabilities should be based on the information from the history of customer interaction with the site.

Transaction complexity discourages customers from completing a purchase, thus requiring more interactive communications (Hanley, 2001). Several e-tailers have already offered live interaction online. Some even offer real-time chat sessions and voice-over-Web capabilities (Jovin \& Lach, 1999).

\section{Customized and Personalized Service}

Personalization means providing a customer with customized information, products, and prices (Morelli, Clark, \& Tesler, 2001). As personal relationships develop, customers will tend to buy more from the company. The more a customer buys from a website, the more likely he or she is to 'stick' with the site.

After-Sales Services: Chow (2000) suggests that e-tailers should integrate quality pre-sale with post-sale customer service. Weintraub (2000) points out that customer relationships should be managed from the pre-sales tracking of prospects, to the ordering and shipping of products, and finally, to the post-sale support of each client. Theis (1999) also suggests that e-firms could increase their profits by initiating a post-sale follow-up procedure by mail or phone based on the 
information gathered before. Thus, e-tailers should not forget their customers after the sale is done. Instead, they should continue to provide after-sales service on their websites.

Goods Return and Refunds: Goods return rate is an indicator of the extent of customer satisfaction (Office.com, 2001). Although both vendors and customers dislike returning goods, it can hardly be avoided (LeClaire, 2001). E-firms should provide a clearly stated goods return policy (cited in Ray, 2001) and instructions on an easy-to-find location on their sites to ensure that customers understand and follow these rules before purchasing (LeClaire, 2001; Tehrani, 2000).

Technical Support: Some e-tailers have already recognized that in order to serve customers better and improve customer relationships, online technical support is another important factor that they cannot ignore. For example, E-SupportDirect, announced by Dell, provides customers with technical support on the Web. Their service automatically indicates when a system fails, allowing a technician to access and repair the system remotely (Briody, 1999).

\section{Website Interface and Information Quality}

Website interfaces that feature easy Search/Help functions, strong navigation features, and good site performance, can best meet customer and e-tailer needs and achieve e-tailing success (META Group, 2000). Lohse and Spiller (1998) suggest a good website should provide Help/Search/FAQs functions, suitable picture size, a "What's new" section, animation, scrolling text, and other special effects.

The rigorous process of accepting an article by an academic periodical guarantees the high quality of their articles (Hawkins, 1999). However, online information does not go through those traditional filters. Everybody can publish a web page. It is hard to know whether the information is the latest, has been checked, whether or not is biased (Pack, 1999), and it can remain there until removed by the author. As such, the credibility and reliability of online information are questionable.

Quality information is a key force driving future Internet shopping, and is essential to establish an active partnership between supplier and consumer. High quality information can encourage suppliers and consumers to understand each other and bring about consumer loyalty and mutual trust (Salaun \& Flores, 2001). The quality of information provided to customers will influence the attractiveness of the website (English, 2001).

Generally speaking, the characteristics for good quality information are: Accessibility, Accuracy, Updated content, Consistency, Sufficiency, and Customization (Zhao \& Gutiérrez, 2001). For example, quality information must be updated, and this is one reason for users to re-visit a website. Updated content, regardless whether it is of interest, of use, or simply for entertainment, can attract users back to the site (Bissonnette, 2001). To keep a site attractive to customers, a site should indicate that it is active and alive by having a last updated time and date, or similar information, e.g. reference to current events (Cotlier, 2001).

\section{Online Service Timeliness}

According to Muthitacharoen (2000), timeliness has an influence on the frequency of purchases online. Some researchers have discovered that many companies take a long time to respond to customer e-mail inquiries, or never reply; as a consequence they will lose a significant degree of credibility and customer loyalty (Hanover, 1998). Therefore, e-firms should reply to customer questions as early as possible (Hendrickson \& Gianforte, 1999).

Increases in download time also have a negative impact on brand attitude (cited in Rose, Straub, $\&$ Lees, 2000). Besides this, poor download times may have other negative consequences as well, 
e.g. they may negatively impact e-consumer attitudes toward the retailer (Rose, Straub, \& Lees, 2000).

The widely reported e-tailing failures in 1999 and 2000 were caused, in many cases, by the delay of goods delivery. As e-commerce continues to grow, e-tailers must try to deliver goods to customers as quickly as possible (Noack, 2000).

\section{Online Security and Trust}

Back in 1995, Cyr (1995) had already warned that lack of security would be a barrier to online shopping. As the Internet becomes increasingly public, security issues have become a matter of high concern.

\section{Public Online Security Concerns}

Issues such as accessing information, protecting consumers from fraud, and protecting their privacy will become increasingly important as more people enter the e-market (Kalakota \& Whinston, 1996). A study conducted in 1999 (citied in Nyshadham, 2000) suggests that online retailers should help customers in overcoming their fears of online security.

\section{Customer Privacy}

As highlighted by eMarketer.com (2002), 'customer service and privacy top the list of hot-button issues'. Internet privacy concerns discourage consumers from shopping on the Internet (Chung \& Paynter, 2000). A recent study shows that $72 \%$ of the surveyed Internet users who did not have online shopping experience said they would do so if they knew how their personal information would be used, but for those who have already shopped online, this makes no difference (Mark, 2001). The New Zealand Privacy Act 1993 states that New Zealand websites that collect customer personal information must place a privacy statement on their sites to clearly state the purpose of the collection and the uses and any disclosures of the information (Ministry of Economic Development, 2000, cited in Chung \& Paynter, 2001). A proposed code for consumer protection of electronic customers in New Zealand states that consumer privacy should be protected during collection and handling, and consumers should be clearly informed about how their personal information will be used (Ministry of Consumer Affairs, 2000). However, Chung and Paynter (2001) found out that privacy is being addressed very poorly on New Zealand websites. Their results show that $65 \%$ of New Zealand websites collect personal data but only $43 \%$ of them state the purposes for collecting the data, and only $37 \%$ of them post a privacy policy statement.

\section{Website Trust}

A few researchers suggest that building trust is a key to the success of e-commerce. For instance, Cotlier (2001) suggests that e-firms have to win the trust of site visitors, because many real-world context cues disappear on the Internet. Pastore (2000) and Ray (2001) indicate that the relationship of e-firms with their customers should be built on trust due to the inability to see actual products, and customer concerns over security.

Electronic Brand Recognition: Electronic brands (e-brands) play a key role in the consumer perception and behavior on the Internet (Levy \& Lendrevie, 1999) and new users prefer to buy from merchants from whom they had previously bought off-line (Kane, 1999, cited in Allen \& Fjermestad, 2000).

Good online customer service leads to good e-brands, exactly the same as in offline customer service. As price is becoming less of a differentiating factor, the combination of brand equity and customer service will lead to business success (Bartels \& Hoffmann, 2001). 
Online Company Goodwill and Prestige: A reputation manager is an independent service that rates quality, credibility, or some other desirable metric for websites, companies, products, or people. Current reputation managers listed on the Useit.com site are eBay, Epinions, Google, Go, Slashdot, and Third Voice. These reputation managers collect data from the users who have dealt with the services or products that are being rated. Each user comments whether he or she is satisfied or dissatisfied (Useit.com, 1999). A company's reputation may motivate consumers to purchase on its website, and consumers may rely on the evaluation comments collected by wellknown reputation managers to decide where to buy.

\section{Online Payment Systems}

Credit cards are the most common and preferred payment method for online shopping (Vargas, 2001). However, the use of credit cards on the Web raises new security issues. A report issued in 2000 concludes that credit card fraud is 12 times more frequent for online merchants than it is for their offline counterparts (Verton, 2001). Credit card fraud diminishes consumer confidence in online transactions and dampens the potential expansion of e-commerce. Some new online payment systems have been developed to solve online credit card security problems. For example, SecureClick uses 'disposable' transaction numbers known only to the authorized customer (Sellitontheweb, 2000).

\section{Online Customer Communities}

An online community is a Web-based system that enables people to work together, educate each other, or sell stuff to each other (Arsdigita Corporation, 2001). A few researchers recommend efirms to build online customer communities, e.g. Bressler and Grantham (2000) state that rapid changes in the business world have resulted in a fast-moving business climate that is affected by culture, technology, and business applications and all these forces are moving businesses towards the growth of communities. Additionally, The eighth strategy to e-commerce success suggested by Seybold (1998) is to foster a customer community. Wilson (1998) also suggests that the most important feature to attract people to a website is 'the feeling that one belongs somewhere, that they are welcome, that you are glad they stopped by'.

\section{Key Barriers to Internet Shopping}

It is evident that a significant number of Internet users have not shopped on the Internet. What barriers discourage them from shopping online? Brown (1999) proposes six key barriers to Internet shopping: Credit card security, Lack of physicality, Quality \& return issues, Lack of awareness of online product offerings, Distribution issues, and Consumer resistance to change.

\section{The Study}

\section{Methodology}

The goals of this study are to explore the critical customer service factors that influence Internet shopping, to obtain the overall online customer perceptions of online customer service, and to reveal the key barriers that discourage Internet users from Internet shopping. Therefore, there was a need to conduct two surveys. The first survey focused on Internet customers who have already purchased online while the second survey focused on Internet users who have not purchased online so that the key barriers that discourage them from Internet shopping can be discovered.

Two initial research models can be established based on the literature reviewed. Figure 1 shows the initial model used for measuring online customer service as perceived by New Zealand Internet customers. 


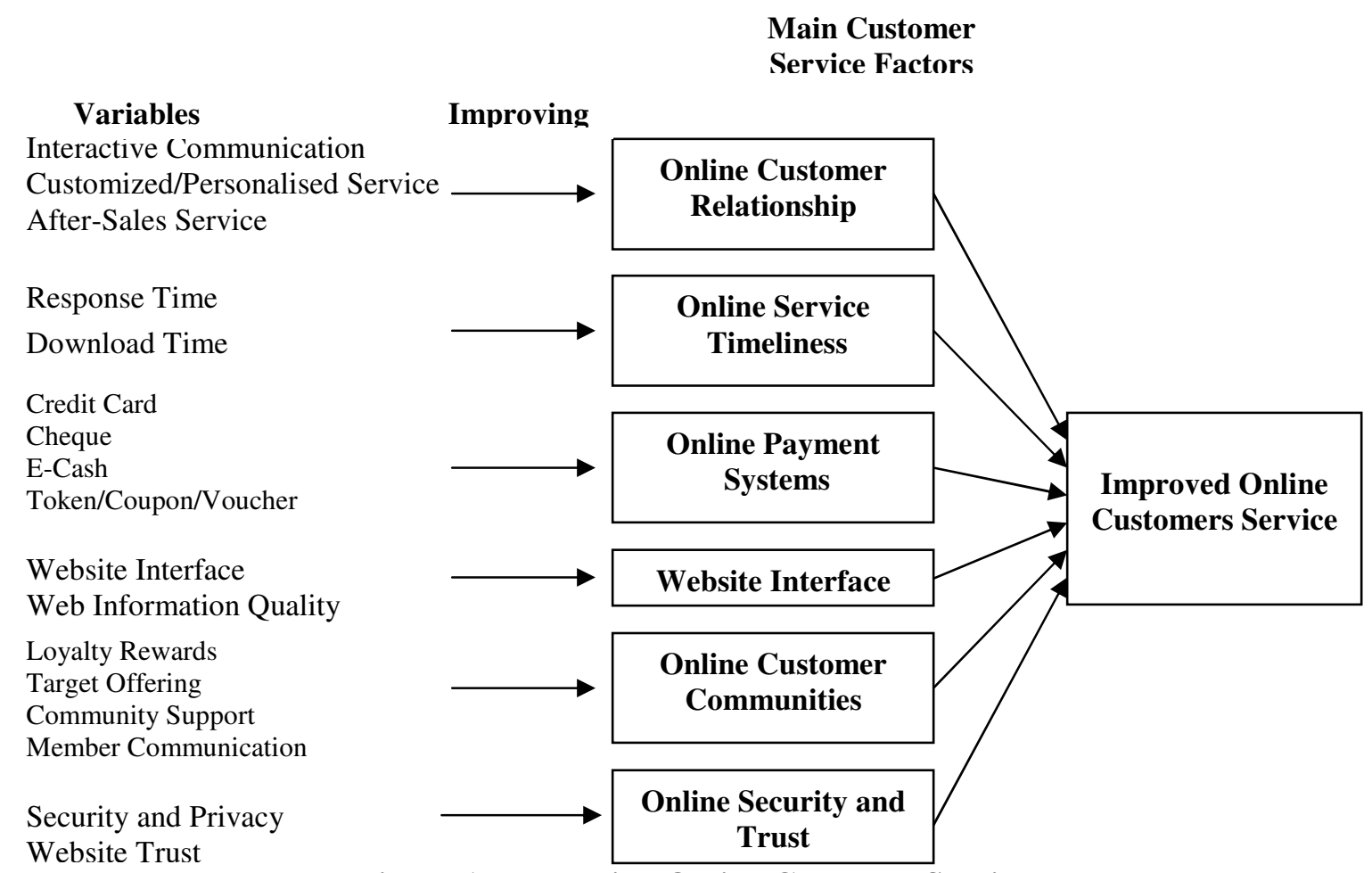

Figure 1: Measuring Online Customer Service

Figure 2 illustrates the second model. It shows the six key barriers that discourage people from Internet shopping and the methods that can be adopted to overcome those barriers.

The first survey was conducted online (heterogeneous population) and the second survey was conducted by distributing hard-copy questionnaires to undergraduate students (a more homogeneous group) in three large classes.

\section{Data Analysis}

SPSS 10.1 was used to analyze the data collected from the two surveys. Factor Analysis was first used to reduce the variables and group these variables into meaningful factors. Next, Analysis of Variance (ANOVA) was used to determine any significant differences in the perceptions of Internet customers about current online customer service across different demographic groups, and also to determine the differences in the perceptions of Internet users about website interface, and online security and trust, and the possibility of doing Internet shopping in the future across different demographic groups.

In this study, the sample sizes for both surveys are 107 and 120 respectively. The histograms show that with the exception of the "Online Customer Communities" service factor, the data meets the normality assumption. 


\section{Methods of Overcoming}

Secure payment protocols

Goods quality and return

Service quality improvements

More picture and information of products available

Distribution improvements

Making order process easy
Key Barri-

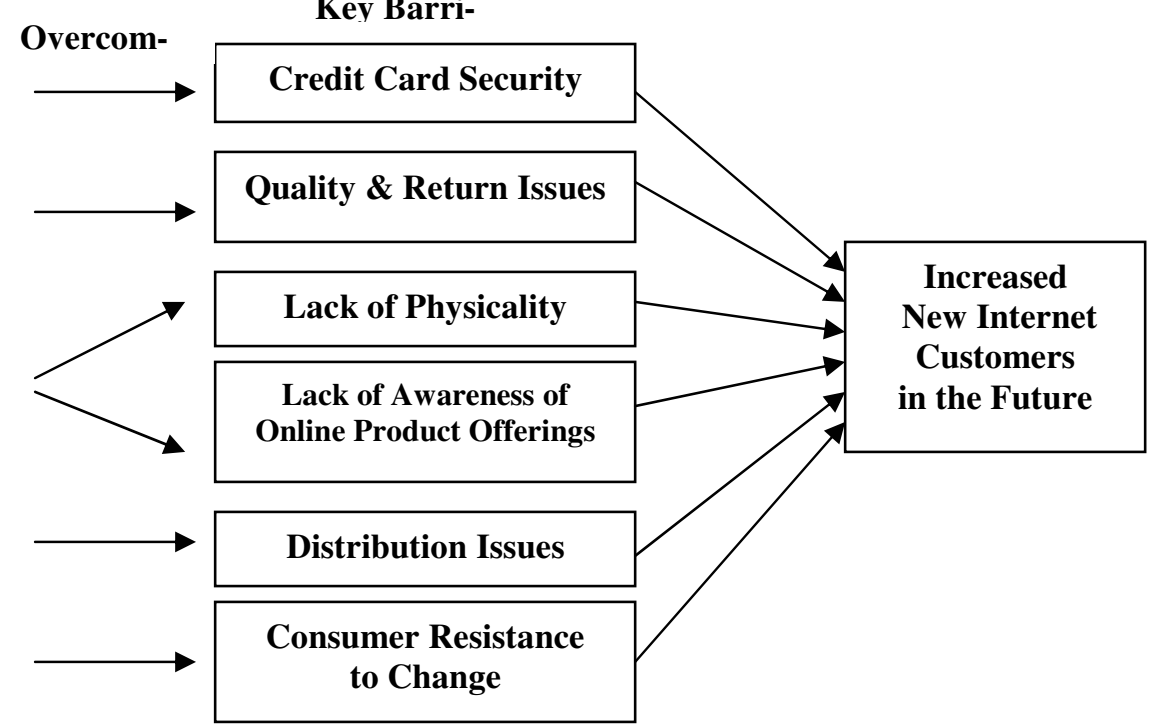

Figure 2: Motivating Internet Shopping

\section{Demographic Comparison}

On average, the customers, i.e. those who have purchased online, have been on the Internet for a longer time, spend more hours on the Internet every week, have visited more retailer sites, earn a higher annual household income compared with the users, i.e. those who have not purchased. However, they have a similar education level and average age. Male respondents are more than twice of female respondents in the first survey, just opposite to the second survey where female respondents are near twice of male respondents.

\section{Results}

In this section, the term "customers" refers to customers who have already purchased online, and the term "users" refers to Internet users who have not purchased online although they have access to the Internet.

\section{The Customers Perception about Online Customer Service}

The research revealed that the customers are only moderately satisfied with current website interfaces, online service timeliness, and online customer relationships. There are some differences across the demographic groups. Customers who have visited a fair number of retailer sites are more satisfied with current website interfaces compared with other customers. Customers who have been on the Internet for a longer time, e.g. more than three years, and those who have a higher annual household income $(\$ 70,000$ - \$99,999) are less satisfied with current online customer relationships than other customers. A combination of experience and higher income can easily result on higher expectations of service.

The findings also showed that customers are not satisfied with current online payment systems and online customer communities. There are also some differences across the demographic groups. Customers, who on average spend a fair number of hours weekly on the Internet, e.g. 11 30 hours, are more satisfied with online payment systems than those who seldom spend time or spend too much time on the Internet. Customers with higher university degrees have a lower satisfaction with current online payment systems than the customers with other levels of education. They also commented that current online payment systems are not flexible and secure, and many 
retailer websites they have visited do not have an online customer community to provide special services.

The customers do have some concerns about online security and trust, and these concerns differ among different age groups. Younger customers $(18-24$ years old) have less concern about online security and trust than older customers. This may be because younger people are more likely to take risks, and are less concerned about security. The customers are less concerned about online security and trust than the users.

Overall, the customers are not satisfied with current online customer service. Customers who have an annual household income of $\$ 70,000$ - $\$ 99,999$ or over $\$ 100,000$ show the highest dissatisfaction with overall online customer service than other income level customers. Table 1 lists the six most important Internet shopping features in the customers' opinion compared with those based on the opinion of worldwide consumers as reported by Retail Industry (2001).

Table 1: The Six Most Important Internet Shopping Features

\begin{tabular}{|c|l|l|}
\hline Rank & \multicolumn{1}{|c|}{ Our Findings (2001) } & \multicolumn{1}{c|}{ Retail Industry Findings } \\
\hline $\mathbf{1}$ & Vendor reliability & Privacy policy for customers personal information \\
\hline $\mathbf{2}$ & Privacy protection & Product return policies \\
\hline $\mathbf{3}$ & Online service timeliness & Clear explanation of shipping and handling fees \\
\hline $\mathbf{4}$ & Information Quality & Product warranties \\
\hline $\mathbf{5}$ & After-sales support & Clear agreements or contracts for services \\
\hline $\mathbf{6}$ & Easy Handling of Returns and Refunds & Detailed product or service descriptions \\
\hline
\end{tabular}

\section{The User Opinions on Internet Shopping}

The users are moderately satisfied with current website interfaces (similar results were found with the customers). They are highly concerned about online security and trust. Their concern about online security and trust is higher than the customers. The users also rank the online security and trust as one of the dominant barriers to Internet shopping. About two thirds of the users remain neutral on doing Internet shopping in the future, and about one third of them think that they are unlikely or very unlikely to do Internet shopping in the future.

\section{The Key Barriers to Internet Shopping}

The users point out the key barriers to Internet shopping, in their view, and the following is a list of these barriers:

Credit Card Security: users worry that their credit card and bank account information may be stolen while shopping on the Internet.

Resistance to Change: users can buy all they want in traditional stores, why bother with Internet shopping?

Lack of Physicality: users cannot physically touch and inspect the products on the Internet.

Hard to Trust: It is hard for them to trust any retailer websites.

Payment not Secure: users worry that the payment methods are not secure.

Additionally the results show that female users are more concerned about privacy protection than males and want to physically inspect the goods before buying. Male users are more resistant to change than females. 
Table 2 is a comparison of the Internet shopping barriers highlighted in our sample with the findings discovered by Brown (1999), Harris and Williams, et al (2000), and Salste (1996). There are some similarities between them, e.g. they all rank Lack of Credit Card Security as the most important Internet shopping barrier.

Table 2: The Comparison of Internet Shopping Barriers

\begin{tabular}{|c|c|c|c|c|}
\hline Rank & $\begin{array}{c}\text { Our Findings } \\
\mathbf{( 2 0 0 1 )}\end{array}$ & $\begin{array}{c}\text { Brown } \\
(\mathbf{1 9 9 9 )}\end{array}$ & $\begin{array}{c}\text { Harris and Williams, } \\
\text { et al (2000) }\end{array}$ & $\begin{array}{c}\text { Salste } \\
(\mathbf{1 9 9 6})\end{array}$ \\
\hline $\mathbf{1}$ & $\begin{array}{c}\text { Credit card secu- } \\
\text { rity }\end{array}$ & Credit card security & Concerns about security & $\begin{array}{c}\text { Lack of vendor reliabil- } \\
\text { ity and security }\end{array}$ \\
\hline $\mathbf{2}$ & $\begin{array}{c}\text { Resistance to } \\
\text { change }\end{array}$ & Lack of physicality & Prefer to go to shops & $\begin{array}{c}\text { Inability to physically } \\
\text { product inspection }\end{array}$ \\
\hline $\mathbf{3}$ & $\begin{array}{c}\text { Lack of physi- } \\
\text { cality }\end{array}$ & $\begin{array}{c}\text { Quality and return is- } \\
\text { sues }\end{array}$ & Not got round to it & $\begin{array}{c}\text { Inability to make prod- } \\
\text { uct comparisons }\end{array}$ \\
\hline $\mathbf{4}$ & Hard to trust & $\begin{array}{c}\text { Lack of awareness of } \\
\text { online product offerings }\end{array}$ & $\begin{array}{c}\text { Like to see things be- } \\
\text { fore buying }\end{array}$ & $\begin{array}{c}\text { Wrong product informa- } \\
\text { tion }\end{array}$ \\
\hline $\mathbf{5}$ & $\begin{array}{c}\text { Payment not } \\
\text { secure }\end{array}$ & Distribution Issues & $\begin{array}{c}\text { Concern about data } \\
\text { protection }\end{array}$ & Delivery delays \\
\hline $\mathbf{6}$ & \multicolumn{2}{|c|}{} & Resistance to Change & \multicolumn{3}{|c|}{} \\
\hline
\end{tabular}

\section{The Motivators to Internet Shopping}

The users only moderately agree with the customers about "Up-to-date Information" as an Internet shopping advantage, but remain neutral on other advantages. The users moderately agree with the customers about most of the Internet shopping disadvantages; however they remain neutral on lack of technical support as an Internet shopping disadvantage. Their agreement on the Internet shopping disadvantages also has a positive impact on their concern about online security and trust, i.e. the more they agree on the disadvantages of Internet shopping, the more they are concerned about online security and trust, and vice versa.

Overall, New Zealand Internet users agree more with the Internet shopping disadvantages than with the advantages. There is also a positive correlation between the user perception of website interfaces and the possibility that they will shop using the Internet in the future.

The five most important Internet shopping features in the users' opinion are: Goods return and refund, Privacy protection, Timely online service, Ease of use, and Help/Support. Other features the users consider may attract them to shop online in the future are Provision of goods not available in local shops, and free delivery.

\section{Internet Customers vs. Internet Users}

This research also reveals that there is no much difference between the customers and users perceptions about website interfaces. However, the customers are less concerned about online security and trust compared with the users.

Table 3: The Comparison of Important Internet Shopping Features

\begin{tabular}{|c|l|l|}
\hline Rank & \multicolumn{1}{|c|}{ Internet Customers } & \multicolumn{1}{c|}{ Internet Users } \\
\hline $\mathbf{1}$ & Vendors' reliability & Goods return and refund \\
\hline $\mathbf{2}$ & Privacy protection & Privacy protection \\
\hline $\mathbf{3}$ & Online service timeliness & Timely online service \\
\hline $\mathbf{4}$ & Information quality & Ease of use \\
\hline $\mathbf{5}$ & After-sales support & Help/Support \\
\hline
\end{tabular}


Table 3 shows a comparison of the five most important Internet shopping features in the opinion of the customers and the users.

\section{Conclusions}

This research discovered that New Zealand Internet customers are not quite satisfied with current online customer service. Online vendors need to improve payment systems and build online customer communities. The important Internet shopping features identified in this paper also need to be provided on their sites. Internet users are just moderately satisfied with current website interfaces, and are very concerned about online security and trust. They rank credit card theft and lack of security as the top barriers to Internet shopping. They consider timely service, clearly stated goods return/refunds and privacy policies as important Internet shopping features.

Online customer service is one of the critical factors to e-commerce success. Other important factors may involve technology, online promotions, revenue models, social policy, management, and product characteristics. Further research on all critical factors should be carried out to establish a complete e-commerce success model. Finally, in order to succeed in global markets, e-tailers must develop their websites to fit the different needs of different countries' online shoppers.

\section{References}

Abrams, A.S. (2000). Internet customer service: Is your pharmaceutical call center prepared? Call Center CRM Solutions, 19 (4), 92-97. October.

Allen, E., \& Fjermestad, J. (2000). E-Commerce strategies: The manufacturer retailer consumer relationship. Proceedings of the American Conference on Information Systems, pp. 872-878. California, U.S.

Arsdigita Corporation (2001). Building an online community. Retrieved February 1, 2002 from http://www.arsdigita.com/books/building-community/introduction

Bartels, R., \& Hoffmann, A. (2001). E-branding in the chemical industry. Chemical Market Reporter, 259 (22), 18. 28 May.

Bissonnette, M. (2001). Modern web site design: Getting people to come back. Retrieved February 1, 2002 from http://www.internalysis.com/nwart2.htm

Bressler, S.E., \& Grantham, C.E. (2000). Communities of commerce. New York: McGraw-Hill.

Briody, D. (1999). Dell takes its support online. Infoworld, 21 (35), 10. 30 August.

Brodsky, N. (1997). The return of customer loyalty. Retrieved February 1, 2002 from http://www.inc.com/articles/details/0,3532,CID1315_REG46,00.html

Brown, K.G. (1999). Internet shopping: Its current status and future potential. Retrieved February 1, 2002 from http://www.comnet.ca/ gbrown/etailing/index.htm?barriers

Chow, E. (2000). Outsourcing e-commerce fulfillment. Warehousing Management, 7 (11), WM12-WM13. December.

Chung, W., \& Paynter, J. (2001). Privacy issues on the Internet: The DOs and the DONTs. Unpublished seminar notes, Department of Management Science and Information Systems Departmental Seminar Series, The University of Auckland. 13 March.

Cotlier, M. (2001). Judging a site by its home page. Catalog Age, 18 (6), 49-50. May.

Cyr, D. (1995). Double click on privacy. Catalog Age, 12 (9), 1, 61+. 1 September.

eMarketer.com. (2002). The eCommerce: B2C Report. Retrieved February 1, 2002 from http://www.emarketer.com/ereports/ecommerce_b2c/welcome.20010629.html

English, L.P. (2001). Information quality management: The next frontier. Annual Quality Congress Proceedings, pp. 529-533. 
Ferrara, C. (2000). Commentary: Customer service differentiates Web retailers. Retrieved February 1, 2002 from http://news.cnet.com/news/0-1007-200-2597106.html

Hanley, P. (2001). Easy com, easy go. Financial Management, p. 14. March.

Hanover, D. (1998). Taking care of shoppers on line. Chain Store Age, 74 (12), 230. December.

Harris, C., Williams, M., et al. (2000). Online shopping. Retrieved February 1, 2002 from http://www.zdnet.co.uk/pcmag/labs/2000/01/eshop/05.html

Hawkins, D.T. (1999). What is credible information? Online, 23 (5), 86-89. September/October.

Hendrickson, K., \& Gianforte, G. (1999). Online customer contact: How much is enough? Telemarketing, 18 (4), 86-92. October.

Hirsch, C. (1999). Building brands on the Web: An old game with new rules. Retrieved February 1, 2002 from http://www.inc.com/articles/details/0,3532,CID15580_REG46,00.html

Jovin, E., \& Lach, J. (1999). Online with the operator. American Demographics, 21 (2), 36-39. February.

Kalakota, R., \& Whinston, A.B. (1996). Frontiers of electronic commerce. New York: Addison-Wesley.

LeClaire, J. (2001). Develop a return and/or exchange policy. Retrieved February 1, 2002 from http://www.inc.com/articles/details/0,3532,CID18499_REG46,00.html

Levy, J., \& Lendrevie, J. (1999). Developing trust in commercial Web sites: A preliminary approach. Abridged version. E-Commerce course book. The University of Auckland.

Lohse, G., \& Spiller, P. (1998). Electronic shopping. Communication of the ACM, 41 (7), 81-87. July.

Mark, A. (2001). Technology promises online anonymity. Catalog Age, 18 (1), 47. January.

McCall, K.L. (2000). Customer retention key to business success. Retrieved February 1, 2002 from http://www.inc.com/articles/details/0,3532,CID17905_REG46,00.html

META Group (2000). Commentary: Fulfillment is the real key to e-tail success. Retrieved February 1, 2002 from http://news.cnet.com/news/0-1007-200-3359016.html

Ministry of Consumer Affairs (2000). A Proposed New Zealand Model Code for Consumer Protection in Electronic Commerce. Appendix one in Electronic Commerce and the New Zealand Consumer: A status report and a proposed New Zealand model code for consumer protection in electronic commerce. March.

Morelli, W., Clark, G., \& Tesler, S. (2001). Up close and personal. Best's Review, 101 (9), 99-100. January.

Muthitacharoen, A. (2000). Consumer's preference between the Internet and conventional stores (An Exploratory Study). Proceedings of the American Conference on Information Systems, pp. 1373-1379. California, U.S.

New Zealand firms wary of ecommerce (2002, August). New Zealand Herald.

Noack, D. (2000). Rapid delivery in cyberspace. Link-Up, 17 (6), 25. November/December.

Nyshadham, E. A. (2000). Consumer perceptions of online transaction security - A cognitive explanation of the origins of perception. Proceedings of the American Conference on Information Systems, California, U.S.

Office.com. (2001). Creating an effective customer service plan. Retrieved February 1, 2002 from http://www.office.com/global//tools/frameset?parameter=ob_tools/legal/customer_service.html?id=38 $\underline{4}$

Pack, T. (1999). Can you trust Internet information? Link-Up, 16 (6), 24. November/October.

Pastore, M. (2000). Customer loyalty key to e-commerce profitability. Markets Retailing. Retrieved February 1, 2002 from http://cyberatlas.internet.com/markets/retailing/article/0,6061_331431,00.html

Ray, A. (2001). How to encourage Internet shopping. Marketing, 41-42. 3 May. 
Retail Industry (2001). Internet Shopping - The Important Features. Retrieved February 1, 2002 from http://retailindustry.about.com/library/weekly/aa000725b.htm

Retailing (2000). Demographic Reports. Retrieved February 1, 2002 from http://tradeport.org/ts/countries/newzealand/mrr/mark0043.html

Rose, G.M., Straub, D.W., \& Lees, J.D. (2000). The effect of download time on consumer attitude toward the retailer in e-commerce. Proceedings of the American Conference on Information Systems, pp. 1352-1354. California, U.S.

Salaun, Y., \& Flores, K. (2001). Information quality: Meeting the needs of the consumer. International Journal of Information Management, 21 (1), 21-37.

Salste, T. (1996). The Internet as a mode of non-store shopping. Retrieved February 1, 2002 from http://www.aivosto.com/vbq5/study.html\#LiteratureReview

Sellitontheweb (2000). New system allows customers to shop without revealing their credit card number. Retrieved February 1, 2002 from http://sellitontheweb.com/ezine/news0409.shtml

Seybold, P.B. (1998). Customers.com: How to create a profitable business strategy for the Internet and beyond. New York: Random House.

Sukpanich, N., \& Chen, L. (2000). Interactivity as the driving force behind e-commerce. Proceedings of the American Conference on Information Systems. pp. 834-836. California, U.S.

Tehrani, R. (2000). The Web customer service Grinch that stole Christmas. Call Center CRM Solutions, 19 (5), 14-18. November.

Theis, P.F. (1999). Transform customer service into a profit center. Zip/Target Marketing, 22 (6), 28. June.

Useit.com (1999). Reputation managers are happening. Retrieved February 1, 2002 from http://www.useit.com/alertbox/990905.html

Vargas, M.T. (2001). What every online retailer needs to know? Retrieved February 1, 2002 from http://retailindustry.about.com/library/weekly/aa000725a.htm

Verton, D. (2001). Manual security procedure aids online fraud arrest. Computerworld, 35 (31), 16. 30 July.

Webb, L.A. (2000). Information requirements determination for electronic retailing: A Consumer-based Perspective. Proceedings of the American Conference on Information Systems, pp. 216-219. California, U.S.

Weintraub, D. (2000). Integration of people application and technology critical for forward success. Ohio CPA Journal, 59 (3), 38-40. July/September.

Wesler, S. (2001). Quality client is the first and most effective marketing tool! Retrieved February 1, 2002 from

http://sbinformation.about.com/smallbusiness/sbinformation/gi/dynamic/offsite.htm?site=http $\% 3 \mathrm{~A} \% 2$ F\%2Fwww.trainingforum.com\%2F123096sw.html

Wilson, J. (1998). Community building. Retrieved February 1, 2002 from http://communitybuilding.com

Zemke, R., \& Connellan, T. (2001). E-Service: 24 ways to keep your customers - when the competition is just a click away. New York: AMACOM, American Management Association.

Zhao, Z., \& Gutiérrez, J.A. (2001). Chapter 1: The fundamental perspectives in E-Commerce. In Mohini Singh \& Thompson Teo (Eds.), E-Commerce diffusion: Strategies and challenges (pp. 3-20). Heidelberg Press.

\section{Biographies}

Zhuojun Zhao graduated as a postgraduate student from the Department of Management Science and Information Systems of the University of Auckland in New Zealand. She gained her Bachelor 
Degree of Commerce with Honors in 2000, and gained her postgraduate Degree of Commerce with Honors in 2002. Her main research interest is to explore the factors that influence the success of e-commerce. She currently works for Xu Ji Zhi Power System Automation Co. Ltd. as an information system engineer.

Jairo Gutiérrez is a Senior Lecturer in Information Systems at the University of Auckland. Previously he worked as an R\&D Manager, Systems Integration Consultant, and Information Systems Manager. He also conducted seminars on LAN/WAN technologies. He teaches data communications and computer networking. His current research topics are in network management systems, programmable networks, and high-speed computer networking. He received Systems and Computer Engineering degree from The University of The Andes (Colombia, 1983), a Masters degree in Computer Science from Texas A\&M University (1985), and a Ph.D. (1997) in Information Systems from The University of Auckland (New Zealand). 